\title{
A study of primary caesarean section in multipara
}

\section{Erika Desai*, Harshraj Leuva, Bakul Leuva, Medha Kanani}

\begin{abstract}
Department of Obstetrics \& Gynecology, SBKS Medical Institute and Research Centre, Pipariya, Ta-Waghodia,
\end{abstract} Vadodara- 391760, Gujarat, India

Received: 12 May 2013

Accepted: 8 June 2013

\section{*Correspondence:}

Dr. Erika Desai,

E-mail: drericadesai@gmail.com

(C) 2013 Desai E et al. This is an open-access article distributed under the terms of the Creative Commons Attribution Non-Commercial License, which permits unrestricted non-commercial use, distribution, and reproduction in any medium, provided the original work is properly cited.

\begin{abstract}
Background: Caesarean delivery is one of the most commonly performed operations today. Caesarean births have become safer. Primary caesarean section in a multipara means first caesarean section done in the patients who had delivered vaginally once or more. Mainly the baby and the placenta are responsible for caesarean section in multipara. Methods: It was a prospective randomized hospital based study of primary caesarean sections performed in multiparous patients at Dhiraj General Hospital at the Department of Obstetrics and Gynecology. In this study analysis of the cases in relation to different factors have been done.

Results: Amongst the various indications for caesarean section in multipara, fetal distress (25.58\%) and antepartum hemorrhage $(22.09 \%)$ were with the highest incidence.

Conclusion: Previous vaginal delivery gives the patient as well as her relatives a false sense of security. There are many cases where a caesarean becomes mandatory for her. The fact that a multipara has had one or more vaginal deliveries should be regarded as an optimistic historical fact, not as diagnostic-criteria for spontaneous delivery of the pregnancy at hand.
\end{abstract}

Keywords: Caesarean section, Multipara, Primipara, Cephalopelvic disproportion

\section{INTRODUCTION}

Caesarean delivery is one of the most commonly performed operations today. Caesarean births have become safer. This is not to imply that they have become safer than normal uncomplicated vaginal deliveries but have become safer than they used to be.

Delivery by caesarean section is most frequently performed in nulliparous for dystocia with suspected cephalopelvic disproportion. At the same time those abnormalities are most common in multipara such as transverse lie, placenta previa are encountered less often than in former years. The major causes of maternal mortality among these women were rupture uterus, hypertensive vascular disease, placenta previa, and malpresentations. ${ }^{1}$

Multipara means those who had delivered once or more after the age of viability. It includes primi-para (unipara- para 1) multipara (para 2,3,4) and grand multipara (para more than 4). In a paper entitled "The dangerous multipara" published in 1934, Dr. Bethel Solomons stated "My object in writing this paper and giving it a sensational title is to remove if possible once and for all, from the mind of the reader, the idea that a primigravida means difficult labour, but a multipara means an easy one. ${ }^{2}$ Feeny was of view that the problems associated with these patients should be emphasized periodically in the literature, as too often complacency on the part of both the doctor and the patient resulted in an unavoidable tragedy. ${ }^{3}$

Primary caesarean section in the multipara means first caesarean section done in the patients who had delivered vaginally once or more. Mainly the baby and the placenta are responsible for caesarean section in multipara. Multipara may still have cephalopelvic disproportion even having previously delivered a full term child vaginally. Since the foetus increases in size with 
multiparity, the size of foetus and foetal head should be carefully estimated. In multiparous patients, malpresentations are favored by a pendulous abdomen and lordosis of the lumbar spine and in any case that is usual for the head not to engage in the pelvis until the onset of labour.

With the introduction of modern technology in the labor wards and neonatology units, there was a further rise in caesarean section. Besides there have been numerous other obstetrics, medical, social, ethical, economic and medicolegal factors which have added to the list of indications leading to alarmingly high rate of caesarean sections all over the world. ${ }^{4}$

It is a common belief amongst public that once a mother delivers her child or children normally, all her subsequent deliveries will be normal as a result such multiparous mothers often neglect routine antenatal checkup. ${ }^{5}$

It is for these reasons that one attention has been directed to the indication for caesarean section in women who have previously delivered vaginally. ${ }^{6}$

\section{Aims of the study}

1. To know the incidence of primary caesarean section in a multipara.

2. To study the incidence and their evaluation.

3. To study the immediate post-operative period and subsequent puerperial period of mother and neonate.

4. To study maternal and fetal morbidity and mortality following operation.

5. To know the perinatal outcome following caesarean section.

6. To study the complications.

\section{METHODS}

Study Design: It was a prospective randomized hospital based study of primary caesarean sections performed in multiparous patients means those who had delivered vaginally once or more (i.e. 28 weeks of gestation or above) at Dhiraj General Hospital at the Department of Obstetrics and Gynecology. In this study analysis of the cases in relation to different factors have been done.

Sample size: The study was done on 86 patients in duration of one and a half years.

\section{Inclusion criteria}

1. Multipara

2. Term pregnancy

3. Singleton pregnancy

\section{Exclusion criteria}

1. Primigravida

2. Previous LSCS

3. Known medical disorders except anemia

4. Gestational age $<37$ weeks

5. Twin pregnancy

Methodology: This includes the patients reporting directly to labor room in various stages of labor as well as those who were admitted in the wards (very few) and taken up for elective lower segment caesarean section. Amongst patients presenting directly to labor room, some patients were first subjected to trial of labor and then subsequently were operated upon. Some were taken up for LSCS straight way. All the patients taken up for study were followed up till they were discharged from the wards. At the time of discharge, the patients were explained about the importance of spacing, contraception and immunization.

\section{RESULTS}

Table 1: Incidence of caesarean section.

\begin{tabular}{|lll|}
\hline & $\begin{array}{c}\text { No of } \\
\text { Cases }\end{array}$ & Percentage \\
\hline $\begin{array}{l}\text { 1. Total Number of } \\
\text { Primary C.S. in Multipara }\end{array}$ & 86 & 29.05 \\
\hline $\begin{array}{l}\text { 2. Total Number of } \\
\text { Primary C.S. in Nullipara }\end{array}$ & 135 & 45.61 \\
\hline 3. Total No. of Repeat C.S. & 75 & 25.34 \\
\hline
\end{tabular}

It was observed that total number of cases of primary C.S. in multipara was $86(29.05 \%)$, total number of cases of primary C.S. in nullipara was $135(45.61 \%)$ and the total number of repeat C.S. was $75(25.34 \%)$.

Table 2: Indications of caesarean section in multipara.

\begin{tabular}{|llll|}
\hline Number & Indication & $\begin{array}{l}\text { No. of } \\
\text { Cases }\end{array}$ & Percentage \\
\hline 1 & Fetal Distress & 22 & 25.58 \\
\hline 2 & APH & 19 & 22.09 \\
\hline 3 & CPD & 17 & 19.77 \\
\hline 4 & $\begin{array}{l}\text { Abnormal } \\
\text { Presentation }\end{array}$ & 15 & 17.44 \\
\hline 5 & $\begin{array}{l}\text { Premature } \\
\text { Rupture of } \\
\text { Membrane } \\
\text { (PROM) }\end{array}$ & 06 & 6.98 \\
\hline 6 & $\begin{array}{l}\text { Prolonged } \\
\text { Labour }\end{array}$ & 04 & 4.65 \\
\hline 7 & Cord Prolapse & 02 & 2.33 \\
\hline 8 & $\begin{array}{l}\text { Threatened } \\
\text { Rupture }\end{array}$ & 01 & 0.01 \\
\hline
\end{tabular}


Table 3: Comparison of indications of caesarean section in multipara and nullipara.

\begin{tabular}{|lllllll|}
\hline Number & Indication & Nulli & Percentage & Multi & Percentage & P-Value \\
\hline 1 & CPD & 37 & 27.40 & 17 & 19.77 & 0.1836 \\
\hline 2 & Fetal Distress & 49 & 36.30 & 22 & 25.58 & 0.0872 \\
\hline 3 & $\begin{array}{l}\text { Abnormal } \\
\text { Presentation }\end{array}$ & 13 & 9.63 & 15 & 17.44 & 0.1586 \\
\hline 4 & APH & 05 & 3.70 & 19 & 22.09 & $0.000^{* *}$ \\
\hline 5 & Prolonged Labour & 20 & 14.81 & 04 & 4.65 & $0.0076^{* *}$ \\
\hline 6 & Prom & 10 & 7.41 & 06 & 6.98 & 0.9044 \\
\hline 7 & Cord Prolapse & 01 & 0.74 & 02 & 2.33 & 0.3734 \\
\hline 8 & Threatened Rupture & - & - & 01 & 0.01 & N.A. \\
\hline
\end{tabular}

Note: ** indicates highly significance

There were different indications for caesarean section in the patients. Fetal distress was the most common indication having highest number of cases $22(25.58 \%)$, next most common being the APH whose cases were 19 (22.09\%), than the number of cases having CPD was 17 (19.77\%), number of patients having Abnormal presentations was $15(17.44 \%)$, patients having Premature rupture of membrane were $6(6.98 \%)$, patients having Prolonged labour were 4 (4.65\%), those having Cord prolapsed were only $2(2.33 \%)$ and the lowest having Threatened rupture and Unstable lie, both were just $1(0.01 \%)$ each.

Table 4: Different types of cases received.

\begin{tabular}{|lll|}
\hline & No. & $\%$ \\
\hline Booked & 24 & 27.90 \\
\hline Unbooked & 62 & 72.09 \\
\hline
\end{tabular}

It was observed that the patients who were booked at our hospital were $24(27.90 \%)$ and unbooked patients were $62(72.09 \%)$. This suggests that even multipara patients do not go for antenatal visits.

Table 5: Different types of cases received.

\begin{tabular}{|ll|l|}
\hline & No. of Cases & Percentage \\
\hline Referred & 39 & 45.34 \\
\hline Direct & 42 & 48.84 \\
\hline Admitted & 05 & 05.82 \\
\hline
\end{tabular}

The number of cases which were referred to us was 39 $(45.34 \%)$, number of cases which were received directly by us was $42(48.84 \%)$ and the number of cases which were already admitted in the ward were $5(05.82 \%)$.

Table 6: Timing of operation.

\begin{tabular}{|lll|}
\hline & No. of cases & Percentage \\
\hline Emergency & 58 & 67.74 \\
\hline Elective & 03 & 03 \\
\hline Delayed C.S.: & & \\
\hline$<6 \mathrm{Hrs}$ & 11 & 12.79 \\
\hline $6-12 \mathrm{Hrs}$ & 11 & 12.79 \\
\hline$>12 \mathrm{Hrs}$ & 03 & 03.49 \\
\hline
\end{tabular}

The number of patients who underwent C-section in Emergency were $58(67.74 \%)$ and number of patients who were selected for elective C-section were $3(03 \%)$. For delayed C-section, the number of patients who were operated within first 6 hours was $11(12.79 \%)$, number of patients who were operated within 6-12 hours was also $11(12.79 \%)$ and those who were operated after 12 hours were $3(3.49 \%)$.

The commonest indication for emergency C-section was $\mathrm{APH}$, for elective $\mathrm{C}$-section one patient had transverse lie whereas 2 had CPD. In cases where C-section was delayed, the commonest indication was fetal distress.

Among the patients undergoing $\mathrm{C}$-section, the number of Primipara patients were $30(34.88 \%)$, number of $2^{\text {nd }}$ para patients were $20(23.26 \%)$, number of $3^{\text {rd }}$ para patients were also $20(23.26 \%)$, number of $4^{\text {th }}$ para patients were 9 $(10.47 \%)$, number of $5^{\text {th }}$ para patients were $4(4.65 \%)$ and number of $6^{\text {th }}$ para patients were just $3(3.49 \%)$. 
Table 7: Parity and frequency of caesarean section.

\begin{tabular}{|lll|}
\hline Parity & No. of Cases & Percentage \\
\hline 1 & 30 & 34.88 \\
\hline 2 & 20 & 23.26 \\
\hline 3 & 20 & 23.26 \\
\hline 4 & 09 & 10.47 \\
\hline 5 & 04 & 4.65 \\
\hline 6 & 03 & 3.49 \\
\hline
\end{tabular}

Table 8: Various causes of maternal morbidity.

\begin{tabular}{|lll|}
\hline Causes & No. of cases & Percentage \\
\hline Wound sepsis & 09 & 10.47 \\
\hline $\begin{array}{l}\text { Abdominal } \\
\text { distension }\end{array}$ & 12 & 13.95 \\
\hline Pyrexia & 10 & 11.63 \\
\hline U.T.I. & 02 & 2.33 \\
\hline P.P.H. & 05 & 5.81 \\
\hline Psychosis & 01 & 1.16 \\
\hline
\end{tabular}

It was observed that the patients undergoing $\mathrm{C}$-section had various incidences of morbidity due to various reasons for it. The number of patients who had wound sepsis after C-section was $9(10.47 \%)$, number of patients with abdominal distension was $12(13.95 \%)$, number of patients having pyrexia was $10(11.63 \%)$ and number of patients having U.T.I. was $2(2.33 \%)$. The number of patients who got P.P.H. was $5(5.81 \%)$ and the number of patients who developed psychosis which is rarely seen was just $1(1.16 \%)$.

\section{DISCUSSION}

Multiparity is a problem associated with poverty, illiteracy, ignorance and lack of knowledge of the available antenatal care and family planning methods. A multipara who has earlier delivered vaginally may still require a caesarean section for safe delivery. In this study, primary caesarean sections in multipara constitute small percentage of total deliveries $(29.05 \%)$ which is quite less than primary caesarean in nullipara, but they are actually associated with high maternal and fetal morbidity.

This study reemphasizes the need of through antenatal care and vigilance in the management of labor. Negligence in which, most of the time needs operative interventions for the good concerns of mother and baby both. Above this, there is a great need to council multipara to report to the hospital as early as possible as many of them are likely to try a home delivery and on failing which they come down to the hospital.

Fetal Distress (25.58\%), APH (22.09\%), CPD (19.77\%) and abnormal presentations $(17.44 \%)$ were the most common indications for caesarean sections. Cases which were received directly rather than referred were more in numbers $(48.84 \%)$ and also the unbooked patients were more $(72.09 \%)$ than the pre-booked cases $(27.90 \%)$ suggesting that even multipara patients do not go for antenatal visits.

Mortality rate at tertiary care hospitals is less because of good antepartum and intrapartum care. Unrecognized cephalopelvic disproportion leading to obstructed labor (in referred cases) is a contributing factor in increasing maternal morbidity. Hence a multipara woman in labor requires the same attention as that of primigravida. Good antenatal and intrapartum care and early referral can reduce the maternal and perinatal morbidity and mortality in multipara.

\section{CONCLUSIONS}

From the above study it is very clear that many unforeseen complications occur in women who previously had a normal vaginal delivery. Multiparity in our society is not by choice. This result in a high birth rate and so many young women become grand multipara. This process causes short birth intervals, eventually jeopardizing the health of the mother and her offspring. This study reemphasizes the need of antenatal care and thorough care and vigilance in the management of labor. Though vaginal delivery is always safer than C-section, difficult vaginal delivery and obstructed labor carries more morbidity and perinatal mortality when compared when compared to elective C-section. Previous vaginal delivery gives the patient as well as her relatives a false sense of security. In many cases, a caesarean becomes mandatory. The fact that a multipara has had one or more vaginal deliveries should be regarded as an optimistic historical fact, not as a diagnostic criteria for spontaneous delivery of the pregnancy at hand.

\section{Funding: None \\ Conflict of interest: None declared}

Ethical approval: The study was approved by the Institutional Ethics Committee

\section{REFERENCES}

1. Eastman N. Multiparity and its effect on maternal and perinatal mortality. Obstet Gynecol Surv 1958;13:833-7.

2. Solomon B. The dangerous multipara. Lancet 1932;2:8-11.

3. Feeny K. The unpredictable multipara. J Irish Med Assoc 1953;32:36-40.

4. Mala Vijaykrishnan, Bhaskar Rao K. Caesarean deliveries- Changing Trends. In: Arulkumaran S, 
Ratnam SS, Bhasker Rao K, Editors. The Management of Labour, $2^{\text {nd }}$ Ed., Hyderabad, Orient Longman, 2005:p.351-63.

5. Basak S, Lahri D. Dystocia in eutocic multigravida. J Obstet Gynaecol India 1975;25:502-7.
6. Jacob S, Bhargava H. Primary caesarean section in multipara. J Obstet Gynaecol India 1972;22(6):64250 .

DOI: $10.5455 / 2320-1770$. ijrcog20130912

Cite this article as: Desai E, Leuva H, Leuva B, Kanani M. A study of primary caesarean section in multipara. Int J Reprod Contracept Obstet Gynecol 2013;2:320-4. 